\title{
Should be Remembered in the Differential Diagnosis of Klatskin Tumour: Alveolar Echinococcosis
}

\author{
Klatskin Tümörünün Ayırıcı Tanisinda Akla Gelmeli: Alveolar \\ Ekinokokkoz
}

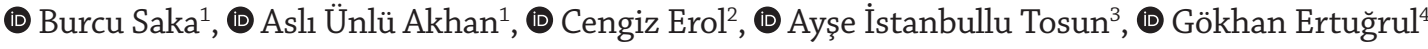

1'stanbul Medipol University Faculty of Medicine, Department of Pathology, İstanbul, Turkey 2İstanbul Medipol University Faculty of Medicine, Department of Radiology, İstanbul, Turkey ${ }^{3}$ İstanbul Medipol University Faculty of Medicine, Department of Microbiology, İstanbul, Turkey ${ }^{4}$ İstanbul Medipol University Faculty of Medicine, Department of General Surgery and Organ Transplantation, İstanbul, Turkey
\end{abstract}

Cite this article as: Saka B, Ünlü Akhan A, Erol C, İstanbullu Tosun A, Ertuğrul G. Should be Remembered in the Differential Diagnosis of Klatskin Tumour: Alveolar Echinococcosis. Turkiye Parazitol Derg 2020;44(3):179-81.

\begin{abstract}
Alveolar echinococcosis is an infectious disease caused by Echinococcus multilocularis and it is frequently diagnosed as a spaceoccupying lesion in the liver. The growth pattern may be similar to that of a malignant tumour with extensive liver infiltration, spreading into neighbouring organs and forming metastasis-like masses in distant organs. Thus, it is one of the differential diagnoses of liver cancer. We report a case that presented as a klatskin tumour clinically and radiologically, but was revealed by pathologic and serologic work-up. Since the courses of these two diseases, a malignancy and an infectious disease, are far beyond comparison, echinococcosis should always be considered in differential diagnosis of obstructive jaundice, especially in the endemic regions.
\end{abstract}

Keywords: Klatskin tumour, biliary obstruction, alveolar hydatid disease

\section{ÖZ}

Alveolar Ekinokokkosis, Echinococcus multilocularis'in sebep olduğu bir enfeksiyon hastalığ1 olup, sıklıkla karaciğerde yer kaplayan lezyon ile kendini gösterir. Karaciğerdeki lokal infiltratif paterni yanısıra, çevre organlara yayllımı ve uzak organlarda metastaz ile karışan kitle oluşturması nedeniyle, malign bir tümörü taklit eder. Bu nedenle karaciğer kanserlerinin önemli bir ayırıcı tanısını oluşturur. Burada, klinik ve radyolojik olarak klatskin tümörünü düşündüren ancak patolojik ve serolojik çalışmalarla Alveoler Ekinokokkosis tanısı alan bir olgu sunulmuştur. Malign tümörlerin ve enfeksiyon hastalıklarının tedavi ve prognozlarının birbirinden çok farklı olması nedeniyle, özellikle Ekinokkozisin endemik olduğu bölgelerde, tıkanma sarılığının ayırıcı tanısında bu etken mutlaka akla gelmelidir.

Anahtar Kelimeler: Klatskin tümörü, safra yolu tıkanıklığı, alveolar hidatid hastalığı

\section{INTRODUCTION}

Echinococcosis is a parasitic infection caused by cestods. Two species have medical importance; Echinococcus granulosus (E. ganulosus) [cause of cystic echinococcosis (CE) a.k.a hydatid cyst disease] and Echinococcus multilocularis (E. multilocularis) (cause of alveolar echinococcosis, a.k.a alveolar hydatid disease). Humans are aberrant intermediate hosts and infected when they swallow eggs in contaminated food (1).

Alveolar echinococcosis (AE) is characterised by an asymptomatic period of five to fifteen years. Under the influence of host's defence mechanisms, the larva can degenerate and die; residual calcified lesions can

Received/Geliş Tarihi: 12.01.2020 Accepted/Kabul Tarihi: 21.04.2020

Address for Correspondence/Yazar Adresi: Burcu Saka, İstanbul Medipol University Faculty of Medicine, Department of Pathology,

İstanbul, Turkey

Phone/Tel: +90 5058530656 E-mail/E-Posta: burcusaka99@gmail.com ORCID ID: orcid.org/0000-0002-2043-2041 
be identified incidentally. The process may also show chronic course, and emergence with cholestatic jaundice as the most common symptom. E. multilocularis does not form cysts as E. granulosus does and presents as space occupying lesion in the liver. The growth pattern resembles that of a malignant tumor with infiltration throughout the liver, spreading into neighbouring organs and mass formations in distant organs, mimicking liver cancer. Its diagnosis is based on clinical and imaging findings, histopathology and serology. Whenever possible complete surgical removal of the lesions should be performed (2-4).

In this article, we report a severe $\mathrm{AE}$ case, which simulates Klatskin tumor clinically and radiologically. The permission was obtained from the institutional ethics committee (date: 19.7.2019, approval number: 581) for the use of patient data for publication purposes.

\section{CASE REPORT}

Seventy four -year-old male patient was admitted because of longlasting pruritus. Physical examination was unremarkable. His cholestatic enzymes were elevated; gamma-glutamyl transferase: 165 U/L and alkaline phosphatase: 245 U/L. Tumor markers were normal. Mild eosinophilia (\%8) was also detected.

Abdominal computed tomography (CT) identified an infiltrative mass, located at the portal hilum, encircling portal vein (PV) and hepatic artery along with infiltration of inferior vena cava. It was constricting PV and obstructing bile ducts (Figure 1a,1b). There was a thrombus formation in the PV and multiple hilar lymphadenopathies. Left liver lob was atrophic, which indicates chronicity. Calcification was not identified. Main radiological differential diagnoses were klatskin tumor and hepatocellular carcinoma. In both cases, the plan was establishment of malignancy to refer the patient for chemotherapy, since the case was unresectable.

Ultrasonography guided fine needle aspiration biopsy was performed with on-site pathology evaluation. Despite the repeated aspirations, material was composed of benign biliary epithelial cells, hepatocytes and inflammatory cells, and suspected malignancy could not be verified. Hereupon, although
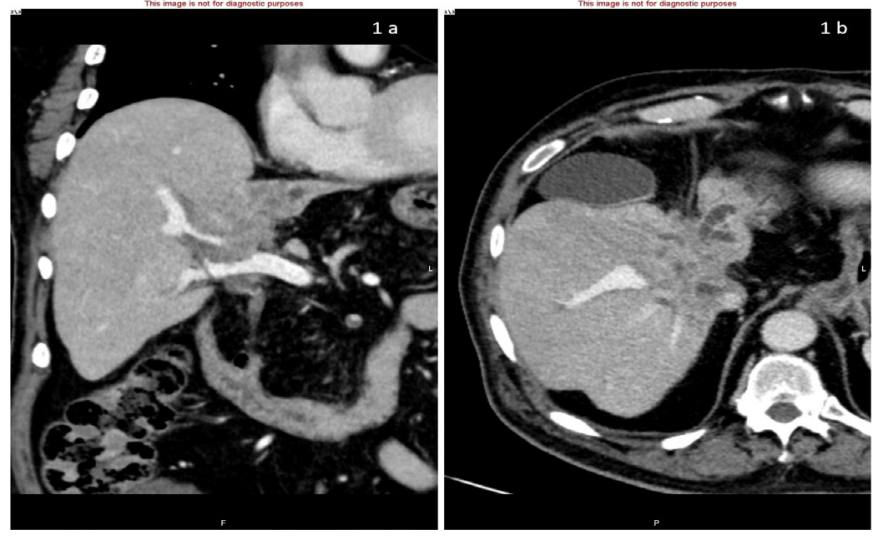

Figure 1. A portal hilar mass encircling major vascular structures and obstructing bile ducts with accompanying lymphadenopathies, giving the impression of carcinoma in an abdominal CT (a: axial plane, b: sagittal plane)

CT: Computed tomography it was not preferred owing to the close relation of the lesion and vascular structures, the procedure was ended with tru-cut biopsy. After these interventions, the patient had hypotensive and hypertensive attacks, flushing and tachycardia for a while.

Hematoxylin-eosin examination of the biopsy revealed necrosis surrounded by palisading macrophages and dense eosinophil leukocyte infiltration. Concentric eosinophilic structures were identified in necrotic debris (Figure 2), compatible with parasitic infestation. Serologic tests detected immunoglobulin $\mathrm{G}$ positivity for E. multilocularis. And the new treatment plan was decided as liver transplantation. He is alive in the fifth year follow-up after transplantation.

\section{DISCUSSION}

AE diagnosis might be complicated as in our case (5-7). Stojkovic et al. (6) reported one third of the AE patients had therapy based on a wrong diagnosis, including $\mathrm{CE}$, intrahepatic cholangiocarcinoma and hemangioma.

The difficulty is multifactorial. Firstly, the most common clinical presentation is obstructive jaundice and/or abdominal pain, which has a long list of differential diagnoses. Radiologic pitfalls are another challenging issue. However, the CT scan has a high sensitivity (95\%) and hypo-attenuation, calcification, and absence of contrast enhancement in a hepatic lesion usually help identify it as $\mathrm{AE}$, these are not detectable in each case (8). Even histopathology cannot achieve the true diagnosis. And serology may not reliably discriminate the species (E. multilocularis or E. granulosus) which leads to non-curative surgical interventions with the risk of toxic cholangitis if protoscolicidal solutions are applied.

Accurate diagnosis requires multidisciplinary approach especially in complicated cases, as ours $(2,9)$. The distinction of these two prediagnoses cannot be overemphasized, since the management is totally different.

\section{CONCLUSION}

When imaging studies revealed a tumor like lesion in the liver, $\mathrm{AE}$ should be kept in mind as a possibility in the endemic regions

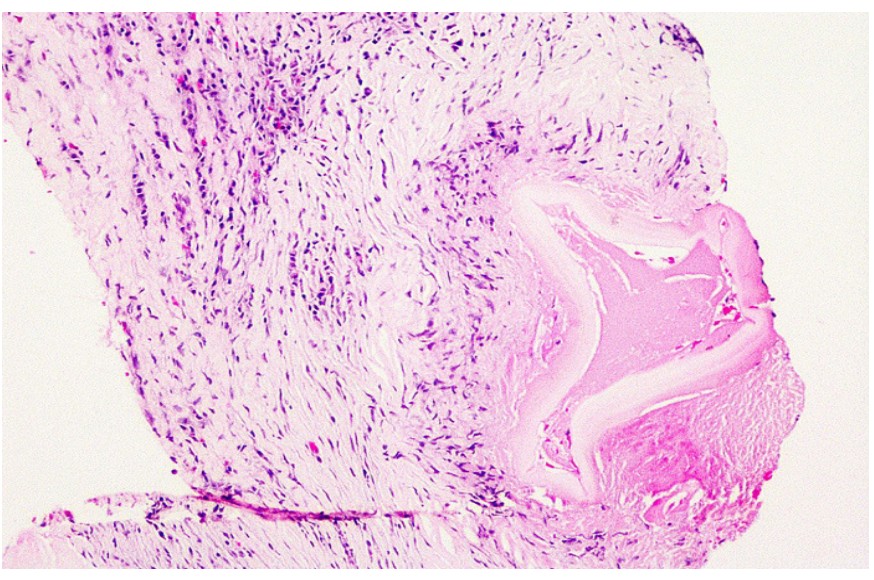

Figure 2. Acellular eosinophilic structure, compatible with parasitic infestation (on the right side of the figure), surrounded by palisading mononuclear inflammation in necrosis (Hematoxylin and eosin stain, x400) 
(North America, Alaska, Central Europe, Turkey, Balkan states and parts of Asia) (10). Correct diagnosis requires multidisciplinary approach and being aware of the traps.

\section{* Ethics}

Informed Consent: The permission was obtained from the institutional ethics committee (date: 19.07.2019, approval number: 581) for the use of patient data for publication purposes.

Peer-review: Externally and internally peer-reviewed.

\section{* Authorship Contributions}

Concept: B.S., C.E., Design: B.S., C.E., Data Collection or Processing: B.S., A.Ü.A., C.E., A.İ.T., G.E., Analysis or Interpretation: B.S., C.E., G.E., Literature Search: B.S., A.Ü.A., Writing: B.S., A.Ü.A., C.E., A.İ.T., G.E.

Conflict of Interest: No conflict of interest was declared by the authors.

Financial Disclosure: The authors declared that this study received no financial support.

\section{REFERENCES}

1. Tümay Gürler A, Bölükbaş CS, Açıcı M, Umur Ş. Overview of Echinococcus multilocularis in Turkey and in the World. Turkiye Parazitol Derg 2019; 43(Suppl 1): 18-35.
2. Brunetti E, Kern P, Vuitton DA, Writing Panel for the WHO-IWGE. Expert consensus for the diagnosis and treatment of cystic and alveolar echinococcosis in humans. Acta Trop 2010; 114: 1-16.

3. Moray G, Shahbazov R, Sevmis S, Karakayali H, Torgay A, Arslan G, et al. Liver transplantation in management of alveolar echinococcosis: two case reports. Transplant Proc 2009; 41: 2936-8.

4. Kern P. Clinical features and treatment of alveolar echinococcosis. Curr Opin Infect Dis 2010; 23:505-12.

5. McManus DP, Li Z, Yang S, Gray DJ, Yang YR. Case studies emphasising the difficulties in the diagnosis and management of alveolar echinococcosis in rural China. Parasit Vectors 2011; 4: 196.

6. Stojkovic M, Mickan C, Weber TF, Junghanss T. Pitfalls in diagnosis and treatment of alveolar echinococcosis: a sentinel case series. BMJ Open Gastroenterol 2015; 2 : e000036.

7. Atanasov G, Benckert C, Thelen A, Tappe D, Frosch M, Teichmann D, et al. Alveolar echinococcosis-spreading disease challenging clinicians: a case report and literature review. World J Gastroenterol 2013; 19: 4257-61.

8. Liu W, Delabrousse E, Blagosklonov O, Wang J, Zeng H, Jiang Y, et al. Innovation in hepatic alveolar echinococcosis imaging: best use of old tools, and necessary evaluation of new ones. Parasite 2014; 21: 74.

9. Sezgin O, Altintaş E, Saritaș U, Sahin B. Hepatic alveolar echinococcosis: clinical and radiologic features and endoscopic management. J Clin Gastroenterol 2005; 39: 160-7.

10. Farrokh D, Zandi B, Pezeshki Rad M, Tavakoli M. Hepatic alveolar echinococcosis. Arch Iran Med 2015; 18: 199-202. 